\title{
PENGARUH PEMBELAJARAN DARING TERHADAP CAPAIAN HASIL BELAJAR SISWA SEKOLAH DASAR
}

\author{
${ }^{1)}$ Yeni Nora Fridayanti, Prodi PGSD, Universitas Negeri Malang \\ email : yeni.nora.1901516@students.um.ac.id
}

\begin{abstract}
This study aims to determine the effect of online learning on the learning outcomes of elementary school students. The research method is carried out through library research by collecting data information related to relevant matters from various sources such as journals, articles, news, books. The criteria for selecting documents, namely that there is a discussion of online learning and the learning outcomes obtained during online learning in elementary schools. The results showed that online learning had an influence on student learning outcomes. This is caused by internal and external factors from students. Elementary school age students are at the concrete operational stage where they are able to do logical reasoning for things that are concrete in nature, while for things that are abstract in nature they are still unable to do it. Students have certain characteristics so they need time to adapt to be able to adjust to online learning. The learning outcomes obtained by students depend on how students respond to the online learning that is being carried out. The role of teachers and parents is very important for the success of students in learning.
\end{abstract}

Keywords : Online Learning, Elementary School, Learning Outcomes

\section{Pendahuluan}

Pandemi virus corona saat ini berdampak bagi seluruh lapisan masyarakat di berbagai bidang seperti ekonomi, sosial, pariwisata, dan pendidikan. Terlihat jelas dalam bidang pendidikan dimana kegiatan pembelajaran dilakukan secara daring untuk mengurangi penyebaran virus corona. Pembelajaran daring adalah pemanfaatan jaringan internet dalam proses pembelajaran. Dengan pembelajaran daring siswa memiliki waktu belajar yang fleksibel yaitu dapat belajar kapanpun dan dimanapun. ${ }^{1}$

Merebahnya pandemi covid 19 mengakibatkan pendidikan di indonesia dilaksanakan secara daring untuk mencegah penularan virus corona. Banyak pro dan kontra terkait pembelajaran yang dilakukan secara daring karena tidak semua siswa dapat beradaptasi dengan penggunaan teknologi namun di sisi lain kesehatan juga berharga dibandingkan harus mengorbankan nyawa atau kesehatan jika pembelajaran dilakukan secara luring. Namun tidak semua siswa bisa berhasil dan mecapai hasil belajar yang memuaskan dalam pembelajaran secara

\footnotetext{
${ }^{1}$ H. A. Rigianti, Kendala Pembelajaran Daring Guru Sekolah Dasar Di Banjarnegara. Elementary School: Jurnal Pendidikan dan Pembelajaran ke-SD-an, 7(2). DOI: https://doi.org/10.31316/esjurnal.v7i2.768, 2020
} 
online karena disebabkan oleh beberapa faktor seperti fakor lingkungan belajar dan karakteristik siswa. $^{2}$

\section{Metodologi}

Penelitian ini menggunakan penelitian kepustakaan. Penelitian kepustakaan adalah teknik pengumpulan data dengan melakukan penelaahan terhadap buku, literatur, catatan, dan berbagai laporan yang berkaitan dengan masalah yang ingin dipecahkan. ${ }^{3}$ Dalam penelitian ini, pengumpulan data diperoleh dari berita dan artikel pada jurnal online. Peneliti melakukan penelusuran artikel dengan menggunakan kata kunci "Pembelajaran daring" dan "Capaian hasil belajar". Kriteria berita dan artikel yang dipilih yaitu adanya pembahasan tentang pengaruh pembelajaran daring dan capaian hasil belajar. Setelah melakukan penelusuran kemudian memilih berita dan artikel yang paling relevan. Teknik penelitian yang dilakukan dengan dokumentasi, yaitu mencari data mengenai hal-hal atau variabel yang berupa catatan, buku, makalah, artikel, jurnal dan berita. ${ }^{4}$

\section{Hasil}

\section{Pembelajaran Daring}

Pembelajaran daring merupakan bentuk penyampaian pembelajaran konvensional yang dimasukkan pada format digital melalui internet. Pembelajaran daring menjadi solusi media penyampai materi antara guru dan siswa saat pandemi covid saat ini. Pada kegiatan pembelajaran luring atau tatap muka, media pembelajaran dapat berupa orang, benda-benda sekitar, lingkungan dan segala sesuatu yang dapat digunakan guru sebagai media atau perantara dalam menyampaikan materi pelajaran. Hal tersebut akan menjadi berbeda ketika pembelajaran dilaksanakan secara daring. Dimana semua media atau alat yang dapat guru hadirkan secara langsung, berubah menjadi media visual karena keterbatasan jarak. ${ }^{5}$

\footnotetext{
${ }^{2}$ P. A. Chusna \& A. D. M Utami, Dampak Pandemi Covid-19 terhadap Peran Orang Tua dan Guru dalam Meningkatkan Kualitas Pembelajaran Daring Anak Usia Sekolah Dasar. Premiere, 2, 1, 11 -30. DOI: https://doi.org/10.51675/jp.v2i1.84, 2020

${ }^{3}$ Moh. Nazir. Metode Penelitian, Jakarta: Ghalia Indonesia, 1988.

${ }^{4}$ Suharsimi Arikunto, Prosedur Penelitian Suatu Pendekatan Praktik. Jakarta: Rineka Cipta, 2010

${ }^{5}$ A. Purwanto, R. Pramono, dkk., Studi Eksploratif Dampak Pandemi COVID-19 Terhadap Proses Pembelajaran Online di Sekolah Dasar. EduPsyCouns: Journal of Education, Psychology and Counseling, 2(1), 1-12. Dari https://ummaspul.e-journal.id/Edupsycouns/article/view/397, 2020
} 
Tujuan dari penelitian ini adalah untuk mendapatkan informasi mengenai pengaruh pembelajaran daring terhadap capaian hasil belajar siswa di sekolah dasar. Apakah pembelajaran daring berpengaruh pada capaian hasil belajar siswa atau tidak.

Untuk mengantisipasi penyebaran virus corona maka pembelajaran dilaksanakan secara daring atau online. Pandemi virus corona jika terus berlanjut akan berdampak pula pada bidang pendidikan. Salah satu dampaknya yaitu siswa mengalami keterlambatan dalam proses pendidikan yang dilakukan. Dalam jangka panjang akan berakibat pada terhambatnya perkembangan kematangan ilmu pengetahuan yang mereka peroleh di masa mendatang. Kondisi pembelajaran daring dapat mengganggu pencapaian hasil belajar dan motivasi belajar siswa. ${ }^{6}$

Di dalam buku "The One World Schoolhouse", Salman Khan mengatakan, "Pendidikan tidak terjadi di dalam ruang antara mulut guru dan telinga murid. Pendidikan terjadi di ruang di dalam otak masing-masing." Hal ini sejalan dengan teori pembelajaran konstruktivisme bahwa ilmu pengetahuan itu dibangun oleh murid melalui proses belajar, bukan dipindahkan dari guru ke murid. Mengingat hal tersebut tidak alasan untuk meragukan bahkan menolak pembelajaran daring.

Secara umum, pembelajaran daring bertujuan memberikan layanan pembelajaran bermutu secara dalam jaringan (daring) yang bersifat masif dan terbuka untuk menjangkau audiens yang lebih banyak dan lebih luas. Pembelajaran daring merupakan pemanfaatan jaringan internet dalam proses pembelajaran. Pembelajaran daring memiliki karakteristik sebagai berikut:

1) Menuntut pembelajar untuk membangun dan menciptakan pengetahuan secara mandiri (constructivism).

2) Pembelajar akan berkolaborasi dengan pembelajar lain dalam membangun pengetahuannya dan memecahkan masalah secara bersama-sama (social constructivism).

3) Membentuk suatu komunitas pembelajar (community of learners) yang inklusif.

4) Memanfaatkan media laman (website) yang bisa diakses melalui internet, pembelajaran berbasis komputer, kelas virtual, dan atau kelas digital.

5) Interaktivitas, kemandirian, aksesibilitas, dan pengayaan. ${ }^{7}$ (Ditjen GTK 2016:6).

\footnotetext{
${ }^{6}$ W. A. F Dewi, Dampak Covid-19 terhadap implementasi pembelajaran daring di Sekolah Dasar. Edukatif: Jurnal Ilmu Pendidikan, 2(1), 55-61. DOI: https://doi.org/10.31004/edukatif.v2i1.89, 2020

${ }^{7}$ Ditjen GTK Kemendikbud, Petunjuk Teknis Program Peningkatan Guru Pembelajar Moda dalam Jaringan (Daring), Jakarta, 2016
} 
Untuk menghasilkan pembelajaran daring yang baik dan bermutu ada beberapa prinsip desain utama yang harus dipenuhi yaitu:

1) Identifikasi capaian pembelajaran bagi siswa, mencakup aspek pengetahuan, keterampilan dan sikap.

2) Menjamin strategi asesmen selaras dengan capaian pembelajaran.

3) Menyusun aktivitas dan tugas pembelajaran secara progresif agar siswa dapat mencapai target pengetahuan, keterampilan dan sikap yang diperoleh dalam proses belajarnya. Dengan cara menyajikan materi yang mendukung belajar aktif. Selain itu juga memperhatikan durasi pembelajaran, pengetahuan dibangun mulai dari yang mendasar lalu meningkat menuju keterampilan pada tingkat yang lebih tinggi seperti aplikasi, integrasi dan analisis.

4) Menjamin keseimbangan antara kehadiran pemberi materi, interaksi sosial, tantangan atau beban kognitif.

\section{Capaian Hasil Belajar}

Hasil belajar adalah kemampuan yang diperoleh seseorang setelah melakukan proses pembelajaran. Seseorang yang telah berhasil dalam belajar akan menunjukkan perubahan pada dirinya. Perubahan dapat ditunjukkan dari kemampuan berpikirnya atau dari sikap terhadap suatu objek. Perubahan dari hasil belajar ini dalam Taksonomi Bloom dikelompokkan dalam tiga ranah (domain), yaitu domain psikomotor atau keterampilan, domain kognitif atau kemampuan berfikir, domain afektif atau sikap. Jadi hasil belajar merupakan suatu perubahan tingkah laku yang bisa diukur dan dapat dievaluasi tinggi rendahnya atau ketercapaiannya berdasarkan ketentuan yang telah ditetapkan. Indikator dapat menguraikan dan mengklasifikasikan seseorang yang dikatakan telah berhasil mencapai tujuan pembelajan seperti dapat menunjukkan perubahan tingkah laku pada dirinya.

\section{Pembelajaran Bagi Siswa Sekolah Dasar}

Pembelajaran pada siswa usia sekolah dasar, sebaiknya disesuaikan dengan karakteristik yang dimiliki dan melakukan analisis kebutuhan yang diperlukan oleh usia anak sekolah dasar. Dengan harapan dapat mengembangkan potensi, menumbuhkan semangat saat proses belajar 
berlangsung, dan mencapai hasil belajar yang optimal. ${ }^{8}$ Dalam pendidikan formal atau pendidikan yang dilaksanakan di lembaga sekolah, maka semua aktivitas belajar tersebut pada prinsipnya untuk mencapai tujuan, pencapaian prestasi belajar, baik dalam bidang kognitif, afektif, maupun psikomotor. Pada masa usia sekolah dasar, sesuai dengan perkembangannya mereka memiliki karakteristik yang unik senang bermain, bergerak, bermain dengan kelompok, senang melakukan atau terlibat secara langsung, masih cengeng, sulit memahami perkataan orang lain, senang diperhatikan dan senang meniru.

Teori perkembangan kognitif yang dikemukakan oleh Piaget menyatakan bahwa anak usia sekolah dasar (usia 7 sampai 11 tahun) pada umumnya berada pada tahap operasional konkret. Pada tahap ini, anak sudah dapat melakukan penalaran secara logis untuk hal-hal yang bersifat konkret, sedangkan untuk hal-hal yang bersifat abstrak masih belum mampu. Dalam proses pembelajaran, tidak semua perencanaan dalapat berjalan dengan lancar. Ada faktor-faktor yang mempengaruhi belajar anak, meliputi faktor internal yaitu keadaan jasmani dan rohani anak, dan faktor eksternal yaitu kondisi lingkungan di sekitar anak. Secara individu, anak terdiri dari dua substansi yaitu fisiologis (fisik) dan psikologis (kejiwaan). Kemudian secara sosial, anak hidup di lingkungannya, baik keluarga masyarakat, dan sekolah. Semua faktor ini, saling berkaitan dan saling mempengaruhi satu sama lain terutama dalam peningkatan pembelajaran anak.

\section{Peran Guru dan Orang Tua}

Guru merupakan faktor penentu yang dominan dalam pendidikan pada umumnya, karena guru memegang peran penting dalam suatu proses pembelajaran. Guru memiliki banyak peran yaitu menjadi pengajar, pemimpin kelas, pembimbing, pengatur lingkungan belajar, perencana pembelajaran, supervisor, motivator, dan sebagai evaluator. Karena guru yang selalu berinteraksi dengan peserta didik maka diharapkan guru dapat menguasai kondisi di lapangan untuk mewujudkan pembelajaran yang menyenangkan dan efektif sesuai dengan kemampuan peserta didik.

Orang tua merupakan orang yang paling dekat dengan anak selama berada di rumah. Orang tua berperan dalam menentukan prestasi belajar anak karena menjadi sosok pertama dan utama dalam pendidikan anak sejak dini. Meskipun anak telah dititipkan ke sekolah, tetapi orang tua

\footnotetext{
${ }^{8}$ Y. Khurriyati, F. Setiawan, \& L. B. Mirnawati, Dampak Pembelajaran Daring Terhadap Hasil Belajar Siswa MI Muhammadiyah 5 Surabaya. Jurnal Ilmiah Pendidikan Dasar, 8(1), 91-104. DOI:

http://dx.doi.org/10.30659/pendas.8.1.91-104, 2021
} 
tetap berperan terhadap prestasi belajar anak. Orang tua merupakan guru pertama dan utama bagi anak-anaknya karena dari orang tua lah anak mendapatkan bimbingan dan kasih sayang yang pertama kalinya. Oleh karena itu, orangtua memegang peranan penting untuk mengatur kondisi belajar di keluarga dan untuk menunjang prestasi belajar anak. Untuk mendidik anak bukan hanya kewajiban guru saja, namun partisipasi orang tua juga sangat penting. Tidak hanya menemani belajar di rumah namun juga menjadi teladan bagi anak-anaknya. Semua kebiasaan baik dan buruk bermula dari pembiasaan yang dilakukan oleh orang tua terhadap anaknya. Oleh karena itu bentuk pola asuh sangat menentukan dalam pendidikan anak untuk mencapai keberhasilan.

Pada saat pembelajaran secara daring, siswa memerlukan waktu untuk beradaptasi menghadapi perubahan baru dengan pembelajaran jarak jauh melalui internet karena sebelumnya mereka belum pernah mengalami peristiwa yang menjadikan mereka diharuskan untuk belajar dirumah. Mereka terbiasa dengan sistem belajar tatap muka di sekolah, berinteraksi dengan temannya, dan bertatap muka dengan guru yang mengajarnya. Bentuk adaptasi atau penyesuaian yang dilakukan oleh siswa tentu akan mempengaruhi daya serap materi pembelajaran oleh siswa dan berdampak pada capaian hasil belajar yang kurang maksimal. Hal ini disebabkan oleh terbatasnya peran guru untuk menjelaskan materi pada pembelajaran daring, penjelasan materi dari guru juga tidak secara langsung dan mendetail karena terbatasnya ruang dan waktu. Maka akan berpengaruh pada kurangnya kemampuan pemahaman siswa terhadap materi yang disampaikan oleh guru sehingga mempengaruhi capaian hasil belajar siswa. Oleh karena itu diperlukan inovasi pembelajaran yang melibatkan teknologi sebagai solusi untuk memaksimalkan hasil belajar.

Pelaksanaan pembelajaran daring menimbulkan permasalahan baru dalam hal memberi penilaian pada siswa. Berdasarkan kurikulum 2013, penilaian kegiatan pembelajaran meliputi aspek afektif, kognitif dan psikomotor. Menurut Anderson ${ }^{9}$ (2003) terdapat tiga prinsip dalam penilaian pembelajaran, yaitu bermakna, transparansi dan adil. Ketiga prinsip tersebut tidak dapat dipenuhi secara maksimal oleh guru saat memberikan nilai pada masa pembelajaran daring seperti ini. Terutama prinsip adil. Adil dalam penilaian mempunyai makna bahwa setiap siswa mempunyai kesempatan yang sama dalam sistem penilaian, bukan berarti bahwa setiap siswa mendapatkan nilai yang sama, tetapi mendapatkan nilai yang sesuai dengan kemampuan belajar

\footnotetext{
${ }^{9}$ L. W. Anderson, Classroom assessment: Enhancing the quality of teacher decision Making, New Jersey: Lawrence Erl-baum Associates Inc., 2003
} 
masing-masing. Namun dengan pembelajaran daring siswa memperoleh nilai maksimal ketika diberi soal. Hal tersebut menjadi pertanyaan bagi guru, apakah siswa benar-benar memahami materi atau siswa mendapatkan bantuan dari orang dewasa ketika mengerjakan tugas. Sehingga yang terjadi adalah guru tidak dapat menilai ketercapaian pembelajaran secara obyektif sesuai dengan kemampuan siswa. ${ }^{10}$

Proses pendampingan orang tua selama masa pandemi memiliki peranan yang sangat penting terhadap kesuksesan belajar siswa. Namun hal ini bukan berarti akan menggantikan tanggungjawab yang seharusnya dilakukan oleh siswa untuk mengerjakan tugasnya. Tugas orang tua hanya sebagai pengarah dan pembimbing dalam proses pembelajaran, penyedia kebutuhan, penyemangat dan memberi pengaruh yang baik. Jika orang tua menggantikan semua tanggungjawab tugas yang harus diselesaikan anaknya maka akan berpengaruh terhadap hasil belajar yang diperoleh anaknya dikemudian hari.

Sebagai seorang pendidik, guru dapat merancang media pembelajaran yang menarik agar materi pembelajaran dapat tersampaikan kepada siswa dengan baik dan tujuan pembelajaran dapat tercapai. Guru dapat memberikan tugas secara variatif yang melibatkan siswa dengan lingkungan sekitar namun yang tidak membahayakan. Seperti membuat karya untuk mengembangkan kreativitas anak, observasi di dalam rumah, mengamati kegiatan keluarga di rumah. Pembelajaran secara daring sebaiknya tidak dilakukan secara monoton dengan pemberian tugas setiap hari. Karena akan membuat siswa cepat bosan sehingga siswa tidak nyaman ketika belajar di rumah.

Peran orang tua yaitu sebagai pendamping, pengawas, dan pengontrol kegiatan belajar anak di rumah. Pendampingan orang tua sangat dibutuhkan pada saat penyampaian materi, membantu menyelesaikan tugas dan membantu setiap kesulitan yang dihadapi oleh anak. Orang tua perlu melakukan pengawasan terhadap keseriusannya dalam belajar. Sesuai dengan perkembangnnya mereka tidak dapat berdiam diri, mudah bosan, tidak fokus. Oleh karena itu orang tua diharapkan mampu mengontrol anak saat belajar di rumah agar mendapatkan hasil belajar yang maksimal.

10 S.A. Nugraha, T. Sudiatmi, \& M. Suswandari, Studi Pengaruh Daring Learning Terhadap Hasil Belajar Matematika Kelas IV. Jurnal Inovasi Penelitian, 1(3), 265-276. DOI: https://doi.org/10.47492/jip.v1i3.74, 2020. 


\section{Kesimpulan}

Pembelajaran daring berpengaruh terhadap capaian hasil belajar siswa. Hal ini disebabkan oleh faktor internal maupun eksternal dari siswa. Siswa usia sekolah dasar berada pada tahap operasional konkret dimana mereka sudah dapat melakukan penalaran logis untuk hal-hal yang bersifat konkret, sedangkan untuk hal-hal yang bersifat abstrak masih belum mampu. Sehingga jika pembelajaran dilakukan secara daring maka akan membuat pembelajaran itu menjadi abstrak, sedangkan kebutuhan dari siswa sekolah dasar yaitu pembelajaran dilakukan secara konkret untuk meningkatkan kemampuan pemahaman siswa terhadap materi yang disampaikan guru sehingga akan berpengaruh pada capaian hasil belajar siswa. Siswa memiliki karakteristik tertentu sehingga membutuhkan waktu beradaptasi untuk dapat menyesuaikan diri dengan pembelajaran daring. Capaian hasil belajar yang diperoleh siswa juga tergantung pada bagaimana siswa menyikapi pembelajaran daring yang sedang dilakukan. Peran guru dan orang tua sangat penting bagi keberhasilan siswa dalam pembelajaran.

\section{Daftar Referensi}

Anderson, L.W. 2003. Classroom assessment: Enhancing the quality of teacher decision Making, New Jersey: Lawrence Erl-baum Associates Inc.

Arikunto, S. 2010. Prosedur Penelitian Suatu Pendekatan Praktik. Jakarta: Rineka Cipta

Chusna, P. A. \& Utami, A. D. M. 2020. Dampak Pandemi Covid-19 terhadap Peran Orang Tua dan Guru dalam Meningkatkan Kualitas Pembelajaran Daring Anak Usia Sekolah Dasar. Premiere, 2, 1, 11 -30. DOI: https://doi.org/10.51675/jp.v2i1.84

Dewi, W. A. F. 2020. Dampak Covid-19 terhadap implementasi pembelajaran daring di Sekolah Dasar. Edukatif: Jurnal Ilmu Pendidikan, 2(1), 55-61. DOI: https://doi.org/10.31004/edukatif.v2i1.89

Ditjen GTK Kemendikbud. 2016. Petunjuk Teknis Program Peningkatan Guru Pembelajar Moda dalam Jaringan (Daring). Jakarta

Khurriyati, Y., Setiawan, F., \& Mirnawati, L. B. 2021. Dampak Pembelajaran Daring Terhadap Hasil Belajar Siswa MI Muhammadiyah 5 Surabaya. Jurnal Ilmiah Pendidikan Dasar, 8(1), 91-104. DOI: http://dx.doi.org/10.30659/pendas.8.1.91-104

Nazir, M. 1988. Metode Penelitian, Jakarta: Ghalia Indonesia

Nugraha, S. A., Sudiatmi, T., \& Suswandari, M. 2020. Studi Pengaruh Daring Learning Terhadap Hasil Belajar Matematika Kelas IV. Jurnal Inovasi Penelitian, 1(3), 265-276. DOI: https://doi.org/10.47492/jip.v1i3.74 
Purwanto, A., Pramono, R., dkk. 2020. Studi Eksploratif Dampak Pandemi COVID-19 Terhadap Proses Pembelajaran Online di Sekolah Dasar. EduPsyCouns: Journal of Education, Psychology and Counseling, 2(1), 1-12. Dari https://ummaspul.ejournal.id/Edupsycouns/article/view/397

Rigianti, H. A. 2020. Kendala Pembelajaran Daring Guru Sekolah Dasar Di Banjarnegara. Elementary School: Jurnal Pendidikan dan Pembelajaran ke-SD-an, 7(2). DOI: https://doi.org/10.31316/esjurnal.v7i2.768 